\title{
Business Strategy for Religious Tourism in Mount Haruman, Indonesia
}

\author{
Dini Turipanam Alamanda \\ Departement of Digital Business, Faculty of Economics, Garut University \\ (email: allamanda.dini.2017@gmail.com) \\ Ikeu Kania \\ Rahyuniati Setiawan \\ Selvi Silfiani Rahayu
}

\begin{abstract}
This study is aimed at investigating the strategy formulation in the development of religious tourism in Mount Haruman by using a SWOT analysis and Quantitative Strategic Planning Matrix (QSPM). The latter was used to determine the recommended strategies to be implemented. The research employed a descriptive qualitative research with a case study approach. The data were collected by using in-depth interviews and distributing questionnaires to a number of key informants around Mount Haruman. The results showed that there were a number of alternative strategies used. The religious tourism managers of Mount Haruman were able to develop their natural potential by holding special events, providing navigation, increasing promotion, providing and developing various facilities, improving the quality of human resources, establishing cooperation and community ownership, planning and developing tourism, maintaining and repairing infrastructure, as well as improving visitor awareness. Based on the analysis of all alternative strategies through QSPM, the strategy that should be implemented and treated as a top priority is to increase promotion. It can be carried out by utilizing information and communication-based technology that is currently developing. The study brings implication that information technology plays a crucial role in tourism development, especially in religious tourism in Mount Haruman.
\end{abstract}

\section{Keywords:}

religious tourism; mountain tourism; tourism development; strategic priority

\section{Introduction}

Tourism in Garut is continuously growing and it makes the local government sets out tourism as the leading sector with hope that it may attract the attention of many investors, and revive the trade sector in Garut Regency which is currently struggling to control its regional income (Indopos, 2018). The program that is being intensified by the government in 
order to foster the growth of Garut tourism is a tourist destination development program by providing activities that can improve the quality of tourist attractions. It is done so that Garut has a tourist destination with national standards.

As there are many Muslims in the country, pilgrimage to the tombs of the religious leaders become quite common activities. As a result, as far as the religious tourism concerns, there is always a business competition between the managers and the local government. Mount Haruman is one of the religious tourism centers in Garut Regency, Indonesia.

In this mountain, there are several sacred tombs that can be found. Some of which are the tomb of Sheikh Jafar Siddiq or better known as Sunan Haruman, Sheikh Malik Ibrahim, and Nyai Fatimah who were the prominent figures in spreading Islam in North Garut and the surrounding areas. The number of visitors to these places reached 40 thousand people in 2015. However, from that time, the number kept decreasing until 2019. Table 1 represents the number of the tourist visits to the religious tourism complex of Mount Haruman for last 5 years.

Table 1.

Tourist Visits to Mount Haruman from 2013 to 2018

\begin{tabular}{cccc}
\hline \multirow{2}{*}{ Year } & \multicolumn{2}{c}{ Number of Tourists } & \multirow{2}{*}{ Total } \\
& International & Domestic & \\
\hline 2013 & - & 38.135 & 38.135 \\
2014 & - & 39.017 & 39.017 \\
2015 & 41 & 40.669 & 40.710 \\
2016 & 31 & 10.583 & 10.614 \\
2017 & 41 & 8.968 & 9.009 \\
2018 & - & 16.485 & 16.485 \\
\hline
\end{tabular}

Source: Tourism and Culture Office of Garut Regency (2019)

\section{Tourism Development}

Grytsiuk et al. (2017) state that tourism which is continuously growing contributes to the economic growth of either developed or developing countries. As one of the most dynamic industries in the current economic conditions, the tourism industry gives contribution to the creation of new jobs and the growth of the country's Gross Domestic Product (GDP).

Tourism development is an effort designed to achieve the successful implementation of tourism sector in order to increase tourists' interest and attention (Aini, 2015). According to Cucculelli and Goffi (2016), a sustainable tourism development will support the preservation of ecological balance that is able to increase competitiveness. 
UNWTO defines sustainable tourism as tourism that concerns with the management of all resources so that economic, social and aesthetic needs can be met while at the same time maintaining cultural integrity, essential ecological processes, biodiversity, and life support systems (Coros et al., 2017). The development of sustainable tourism should also be supported by the inclusion, equity, synergy, reciprocity, social balance and responsibilities, environment and culture (Cortez, 2010).

Grytsiuk (2017) explains that in order to achieve the goals of the strategic planning of tourism development, there are practical tasks that need to be carried out. They are explained as follows:

1) Improving the quality of tourism services;

2) Being able to adapt to the market needs that affect the tourists;

3) Maximizing the company revenue by reducing the cost of tourism services when setting up the market prices;

4) Optimizing business costs, developing the motivation and evaluation criteria of the staffs, and planning the types of tourism activities;

5) Monitoring the main indicators of the company's financial and economic activities;

6) Developing the organizational structure and financial system of the company;

7) Creating pricing policies for tourist services in various seasons and times;

8) Encouraging intensive development in advertising the company activities.

Kong et al. (2015) explain that the first step towards sustainable tourism development is to identify the stakeholders to further gain their understanding regarding tourism planning and development. To realize this step, the government should strengthen its role in this field and form an effective working model among the government, business people, and society (Grytsiuk et al., 2017)

Compliance to the sustainable tourism development that take the specific objectives of each region into account while still preserving its environment is one of the aspects that must be considered in developing a sustainable tourism development strategy. The following are the principles that become the basis of sustainable tourism (Ene \& Bărăitaru, 2010):

1) Minimizing the impacts of tourism on the natural environment to achieve environmental sustainability by contributing to the maintaining and improving the conservation status by returning a portion of the revenues from the protected areas. 
2) Minimizing the negative impacts of tourism on the local communities to achieve social sustainability. It can be achieved by developing forms of tourism that do not disrupt the daily lives of the local residents. It is important in order to avoid the occurrence of strained relationship with the local community.

3) Minimizing the negative impacts of tourism on cultures / traditions / habits of the local community to achieve cultural sustainability.

4) Maximizing the benefits of the local economy as a result of tourism development to achieve economic sustainability. It is one of the most important principles of sustainable tourism in which it provides protection services and encourage the economic development of the local communities and protected areas.

5) Providing education, training, and information for all those involved in the tourism activities. Educating the tourists through a higher understanding and appreciation of their impacts in order to improve personal attitudes and reduce the environmental impacts. This includes the ecological education components for visitors, residents, local government, rural and urban populations, etc.

6) Creating local control as a basic principle of sustainable tourism, namely by involving local communities in all matters regarding sustainable tourism development, and being an active part of decision makers.

\section{Tourism Marketing}

Marketing emerges as a new framework and paradigm that enables marketers to increase value for all stakeholders in tourism by revolutionizing their offerings and jointly creating products and services dynamically with the consumers (Buhalis \& Foerste, 2015). Butcher \& Smith (2017) state that tourism industry throughout the world is receiving a significant impact from the information technology as a search engine platform. It has an impact on the general performance of online tourism activities. Kotoua and Ilkan (2017) explain that computer ownership among tourists has increased internet consumption on marketing channels in various tourist destinations. Luo et al (2012) suggest the promotion of websites and advertisements on the internet as it is easily accessed by the tourists around the world and even those in the smallest villages. Serving the tourists with internal and external 
contextual information through mobile devices is an innovative and powerful form of marketing that may help creating better tourism experience (Wang \& Xiang, 2012).

\section{Religious Tourism}

Continuing the results of research by Jee et al. (2019) which states that the atmosphere, cultural environment, and brand destinations of community-based tourism destinations, as well as the attachment of objects to their visitors and the intention to revisit, are potential marketing strategies to be developed. The religious tourism of the Mount Haruman is a tourist attraction with these characteristics. Imandaneifar et al. (2014) view religious tourism as one of the oldest types of tourism that is currently developing throughout the world. It is rooted in the religious beliefs which manifest into the activities such as visiting religious sites for religious experience. According to Fluker and Turner (2000) in Haq (2014), religious tourism is practiced for various motives including achieving self-actualization and personal well-being, as well as fulfilling spiritual needs which are at the center of human social psychology regardless of race, skin color, belief, religion, and etc.

Ulumudin et al. (2019) claim that among the Indonesian boarding school communities, there is a shift in the tourism paradigm, from the "sun, sand and sea" to the "tranquility, sustainability and spirituality". Furthermore, although the majority of Indonesians are Muslim, religious tourism still has not received proper attention either from the government or investors. The development of religious tourism in Indonesia, which consists of architecture, mosques, Islamic teachings and others, cannot stand alone. It needs to be combined or integrated with the natural tourism, cultural tourism or other tourisms (Pasya \& Gitasiswhara, 2013).

Due to the fluctuating number of tourist visits, the parties involved in the management of the religious tourism of Mount Haruman need to reconsider the strategic steps that must be taken. They need to develop and reconstruct the important factors in their tourism. Therefore, this study aims to identify the strategy formulation in the development of religious tourism in Mount Haruman Garut by using a SWOT analysis in which the External Factor Analysis (EFA) and Internal Factor Analysis (IFA) matrices become the tools used. Furthermore, the study also utilized the Quantitative Strategic Planning Matrix (QSPM) to determine which alternative strategies that highly need to be implemented. 


\section{Methods}

\section{Research Characteristics}

The research utilized descriptive qualitative method with a case study approach. This case study on the religious tourism development strategy in Mount Haruman aims to find out the situation in the area and the community evaluation on the tourism system. It was done to provide an overview of the internal and external factors that influence the tourism in Mount Haruman which is expected to then become the basis for the formulation of tourism development strategies. The data consisted of primary data which were gained through observation, interviews and questionnaires distributed to a number of informants, as well as secondary data in the form of literature study. By using the snowball sampling method, the study obtained 3 key informants and the data collection process was carried out through the following stages.

\section{Profil of Informants}

In this research, the informants to be interviewed were selected based on the specific criteria i.e. the informant's knowledge on the information needed. The informants are the descendant of Sheikh Jafar Siddiq, namely MA the representative of the Assalafiyah Islamic Boarding School, namely NS who is also the representative of residents around the Great Mosque of Syekh Jaffar Siddiq, and the representative of the residents around Mount Haruman namely AS. The descriptions of each informant in this study are explained as follows:

1) First Informant

The first informant was a descendant of Sheikh Jaffar Siddiq, MA. He was chosen as one of the informants because he is the person who knows the history of Sheikh Jaffar Siddiq as an influential figure in the spread of Islam at that time.

2) Second Informant

The second informant was the representative of the Assalafiyah Islamic Boarding School, NS. She was also the representative of residents around the Great Mosque of Sheikh Jaffar Siddiq. She was chosen as one of the informants as she is the local resident who knows the stories that develop in the community, and how the development of religious tourism on Mount Haruman is progressed. 
3) Third Informant

The third informant was the representative of the residents around Mount Haruman religious tourism area, AS. He was chosen as one of the informants because he is one of the sellers who always stay in the tourism area. This means that he knows every change and development in Mount Haruman.

\section{Data Analysis}

This study employed four matrix as its analysis models. They were the IFE Matrix, EFE Matrix, TOWS / SWOT Matrix and QSPM which were carried out in three stages of implementation. SWOT analysis was used to determine the internal and external conditions of the object under study, while QSPM analysis was used as a follow-up analysis to determine the alternative strategy to be implemented.

\section{The Input Stage}

In this stage, IFE (Internal Factor Evaluation) Matrix and EFE (External Factor Evaluation) Matrix were used. The IFE matrix was utilized to determine the internal factors i.e. strengths and weaknesses, while the EFE Matrix was employed to evaluate the external factors i.e. opportunities and threats. The steps in preparing these two matrices included:

1) Identifying the internal and external strategic factors of the objects under study.

Identifying the strengths and weaknesses by making a list of each factor based on the results of interviews with the key informants. The data were presented with the positive factors (strengths and opportunities) written before the negative factors (weaknesses and threats).

2) Assigning weights for each factor

Weights are obtained from the average of the informants' answers on how important these factors are compared to the overall internal or external factors, using the scale from 0.20 (very important), 0.15 (important), 0.10 (quite important), 0.05 (not important) to 0.0 (very unimportant) which if it is totaled with all the factors, it should not exceed 1.

3) Rating each factor. Rating represents how effective the current strategy is with response to the existing strategic factors. The ranking of these factors is determined by filling out the questionnaire. The rating is based on the following information: 
For IFE:

$1=$ very weak

2 = slightly weak

$3=$ strong enough

$4=$ very strong
For EFE:

$1=$ below average

$2=$ average

$3=$ above average

$4=$ very good

4) Calculating the scores of the weights and rating of each factor. The scores were obtained by multiplying the weights with the rating score. The total score was obtained by summing all the scores.

\section{The Matching Stage}

In this stage, the TOWS / SWOT Matrix was used. This matrix is a matching tool developed to describe how opportunities and threats (external factors) are adjusted to the strengths and weaknesses (internal factors). The TOWS / SWOT matrix produced four possible alternative strategies. The steps for preparing this matrix are as follows:

1) Listing the company's external opportunities and threats, as well as the company's internal strengths and weaknesses.

2) Developing an $\mathrm{SO}$ (Strength-Opportunity) strategy by matching the internal strengths and the external opportunities.

3) Developing a WO (Weakness-Opportunity) strategy by matching the internal weaknesses and the external opportunities.

4) Developing a ST (Strength-Threat) strategy by matching the internal strengths and the external threats.

5) Develop a WT (Weakness-Threat) strategy by matching the internal weaknesses and external threats.

\section{The Decision Stage}

In this stage, QSPM was used as an analysis tool to objectively evaluate the alternative strategies based on the main internal-external factors identified in the previous stage. The steps in preparing the QSPM matrix are as follows:

1) Making a list of external opportunities or threats and internal strengths or weaknesses in the left column of QSPM. This information was obtained from the IFE Matrix and the EFE Matrix. 
2) Giving weights to each internal and external factor according to the weights gained on the IFE and EFE matrix.

3) Matching and identifying the alternative strategies that will be considered for implementation.

4) Obtaining the Attractiveness Scores (AS) which shows the relative attractiveness for each strategy with the conditions as follows:

$1=$ not attractive;

2 = slightly attractive;

3 = quite attractive;

4 = very attractive.

5) Calculating the attractiveness score by multiplying the weights of the attractiveness scores in each row.

6) Summing up the Total Attractiveness Scores (TAS) in each QSPM column. The highest TAS indicates the main alternative strategy, while the smallest TAS indicates the last choice of strategy.

\section{Results and Discussion}

The first step taken was to identify the SWOT factors by interviewing the key informants consisting of Syekh Jafar Siddiq's descendant, MA, the representative of the Assalafiyah Islamic Boarding School, NS and the representative of the resident around Mount Haruman religious tourism area, AS. Table 2 and Table 3 present the results of internal and external mapping factors.

Table 2.

Internal Factor Evaluation

\begin{tabular}{|c|c|c|c|c|}
\hline No & Internal Key Factors & $\begin{array}{l}\text { Average } \\
\text { Rating }\end{array}$ & $\begin{array}{l}\text { Average } \\
\text { Weight }\end{array}$ & Score \\
\hline \multicolumn{5}{|c|}{ Strengths } \\
\hline S1 & $\begin{array}{l}\text { Religious tourism of Mount Haruman is an tourism object } \\
\text { with special attraction, that is, religious tourism. It is located } \\
\text { in Cibiuk Subdistrict }\end{array}$ & 4,00 & 0,09 & 0,35 \\
\hline S2 & $\begin{array}{l}\text { Religious tourism of Mount Haruman is a sacred place with } \\
\text { spectacular scenery. }\end{array}$ & 4,00 & 0,09 & 0,35 \\
\hline S3 & $\begin{array}{l}\text { Religious tourism of Mount Haruman is a sacred place with } \\
\text { cool air. }\end{array}$ & 4,00 & 0,09 & 0,35 \\
\hline
\end{tabular}




\begin{tabular}{|c|c|c|c|c|}
\hline No & Internal Key Factors & $\begin{array}{l}\text { Average } \\
\text { Rating }\end{array}$ & $\begin{array}{l}\text { Average } \\
\text { Weight }\end{array}$ & Score \\
\hline S4 & $\begin{array}{l}\text { Religious tourism of Mount Haruman has a special bale } \\
\text { (center) at each tomb complex as a place for tourists to pray. }\end{array}$ & 3,33 & 0,08 & 0,26 \\
\hline S5 & $\begin{array}{l}\text { Religious tourism of Mount Haruman has a rare chili tree } \\
\text { from which sambal (sauce) cibiuk was made }\end{array}$ & 2,50 & 0,06 & 0,16 \\
\hline S6 & $\begin{array}{l}\text { Religious tourism of Mount Haruman is a heritage site with } \\
\text { a high historical value. }\end{array}$ & 4,00 & 0,09 & 0,35 \\
\hline S7 & $\begin{array}{l}\text { The location of Mount Haruman religious tourism is easily } \\
\text { accessed by tourists. }\end{array}$ & 3,33 & 0,07 & 0,25 \\
\hline S8 & $\begin{array}{l}\text { The location of Mount Haruman religious tourism is close to } \\
\text { the other tourist attraction, namely the typical culinary tour } \\
\text { of Cibiuk. }\end{array}$ & 4,00 & 0,09 & 0,35 \\
\hline \multicolumn{5}{|c|}{ Weaknesses } \\
\hline $\begin{array}{c}\mathrm{W} \\
1\end{array}$ & It is yet recognized by the people of Garut Regency & 2,67 & 0,06 & 0,16 \\
\hline $\begin{array}{l}W \\
2\end{array}$ & $\begin{array}{l}\text { The environmental cleanliness at the tourism area is not well } \\
\text { preserved }\end{array}$ & 3,00 & 0,07 & 0,21 \\
\hline $\begin{array}{l}W \\
3\end{array}$ & $\begin{array}{l}\text { The unavailability of comprehensive concepts regarding the } \\
\text { development of religious tourism in Mount Haruman. }\end{array}$ & 2,67 & 0,06 & 0,17 \\
\hline $\begin{array}{l}W \\
4\end{array}$ & Lack of human resources. & 2,67 & 0,06 & 0,17 \\
\hline $\begin{array}{l}W \\
5\end{array}$ & Lack of supporting facilities, such as lodge & 4,00 & 0,09 & 0,35 \\
\hline \multicolumn{3}{|c|}{ Total Score } & 1 & 3,48 \\
\hline
\end{tabular}

Table 3.

External Factor Evaluation

\begin{tabular}{llccc}
\hline No & \multicolumn{1}{c}{ External Key Factors } & $\begin{array}{c}\text { Average } \\
\text { Rating }\end{array}$ & $\begin{array}{c}\text { Average } \\
\text { Weight }\end{array}$ & Score \\
\hline Opportunities & 4,00 & 0,12 & 0,47 \\
\hline O1 $\quad \begin{array}{l}\text { Rabiul Awal and Rajab are the most visited time. } \\
\begin{array}{l}\text { The history of sambal cibiuk which is passed down from } \\
\text { Oheikh Jaffar Siddiq's daughter, Nyimas Siti Fatimah, is one } \\
\text { of the things that attract the visitors to come. }\end{array}\end{array}$ & 3,67 & 0,11 & 0,40 \\
$\begin{array}{l}\text { The development of rafting has the potential to become an } \\
\text { additional tourist attraction that increases the attractiveness } \\
\text { of the tourist destination. }\end{array}$ & 2,33 & 0,07 & 0,17 \\
$\begin{array}{l}\text { The addition of paragliding has the opportunity to become } \\
\text { additional tourist attractions that increase the attractiveness } \\
\text { of tourist destination }\end{array}$ & 2,67 & 0,08 & 0,21 \\
$\begin{array}{l}\text { Religious tourism of Mount Haruman has the potential to } \\
\text { become a source of community income }\end{array}$ & 4,00 & 0,12 & 0,47
\end{tabular}




\begin{tabular}{llccc}
\hline \multicolumn{1}{c}{ External Key Factors } & $\begin{array}{c}\text { Average } \\
\text { Rating }\end{array}$ & $\begin{array}{c}\text { Average } \\
\text { Weight }\end{array}$ & Score \\
\hline $\begin{array}{l}\text { Religious tourism of Mount Haruman is a tourist destination } \\
\text { that is visited by many tourists from outside the Garut area, } \\
\text { especially from Nahdlatul Ulama. }\end{array}$ & 4,00 & 0,12 & 0,47 \\
\hline Threats & & & \\
\hline $\begin{array}{l}\text { The existence of egocentric community which makes the } \\
\text { development of the religious tourism in Mount Haruman get } \\
\text { hampered. }\end{array}$ & 3,33 & 0,09 & 0,31 \\
T2 $\begin{array}{l}\text { The unwillingness of the people to be opened to investors } \\
\text { who want to develop the area }\end{array}$ & 3,67 & 0,10 & 0,36 \\
T3 $\begin{array}{l}\text { A high concern from people about the changing of the } \\
\text { management status. }\end{array}$ & 3,67 & 0,10 & 0,36 \\
T4 $\quad \begin{array}{l}\text { The lack of visitor awareness of environmental cleanliness. } \\
\quad \text { Total Score }\end{array}$ & 3,33 & 0,09 & 0,31 \\
\hline
\end{tabular}

The average score is 2.5. The total score lower than 2.5 indicates weak internal position, while that of higher than 2.5 indicates a strong internal position. Table 2 shows that the IFE Matrix score is 3.48 which means that Mount Haruman religious tourism has a strong internal position. A total score of 4.0 indicates that the organization responds very well to the opportunities and threats emerged. Meanwhile, a total score of 1.0 indicates that the organization does not take advantage of the emerging opportunities or does not make any attempt to avoid external threats. Moreover, from Table 3, it can be seen that the EFE Matrix score is 3.55, which means that religious tourism stakeholders of Mount Haruman respond very well to the opportunities and threats that exist.

Next to those findings are the proposed strategies as the results of the SWOT analysis presented in Table 2 and Table 3. Each proposed strategy is given a TAS code. Of the 23 strategy indicators, 11 TAS were obtained. Based on the results of TOWS / SWOT Matrix, several alternative strategies to support the development of religious tourism on Mount Haruman were produced. In determining the prioritized alternative strategy, a QSPM analysis was carried out using an attractiveness scores on a scale of 1 to 4 with $1=$ attractive, 2 = slightly attractive, 3 = attractive enough, and $4=$ very attractive. The results of the QSPM analysis can be seen in Table 4 .

Table 4. 


\begin{tabular}{|c|c|c|c|c|c|c|c|c|c|c|c|c|}
\hline \multirow{4}{*}{\multicolumn{2}{|c|}{ Key Factors }} & \multicolumn{11}{|c|}{ Strategic Alternatives } \\
\hline & & \multirow{3}{*}{$\begin{array}{c}\mathbf{1} \\
\text { TA } \\
\mathrm{S} \\
\end{array}$} & \multirow{3}{*}{$\begin{array}{c}2 \\
\text { TA } \\
\text { S } \\
\end{array}$} & \multirow{3}{*}{$\begin{array}{c}3 \\
\text { TA } \\
\text { S } \\
\end{array}$} & \multirow{3}{*}{$\begin{array}{c}4 \\
\text { TA } \\
\text { S } \\
\end{array}$} & \multirow{3}{*}{$\begin{array}{c}5 \\
\text { TA } \\
\text { S } \\
\end{array}$} & \multirow{3}{*}{$\begin{array}{c}6 \\
\text { TA } \\
\text { S } \\
\end{array}$} & \multirow{3}{*}{$\begin{array}{c}7 \\
\text { TA } \\
\text { S } \\
\end{array}$} & \multirow{3}{*}{$\begin{array}{c}8 \\
\text { TA } \\
\text { S } \\
\end{array}$} & \multirow{3}{*}{$\begin{array}{c}9 \\
\text { TA } \\
\text { S } \\
\end{array}$} & \multirow{3}{*}{$\begin{array}{c}10 \\
\text { TA } \\
\text { S } \\
\end{array}$} & \multirow{3}{*}{$\begin{array}{c}11 \\
\text { TA } \\
\text { S } \\
\end{array}$} \\
\hline & & & & & & & & & & & & \\
\hline & & & & & & & & & & & & \\
\hline \multicolumn{13}{|c|}{ Opportunities } \\
\hline 1 & $\mathrm{O} 1$ & 0,43 & 0,43 & 0,39 & 0,47 & 0,39 & 0,47 & 0,39 & 0,47 & 0,47 & 0,47 & 0,43 \\
\hline 2 & $\mathrm{O} 2$ & 0,36 & 0,36 & 0,36 & 0,43 & 0,40 & 0,43 & 0,40 & 0,43 & 0,40 & 0,43 & 0,40 \\
\hline 3 & $\mathrm{O} 3$ & 0,14 & 0,19 & 0,26 & 0,26 & 0,26 & 0,24 & 0,26 & 0,28 & 0,24 & 0,28 & 0,21 \\
\hline 4 & $\mathrm{O} 4$ & 0,21 & 0,24 & 0,27 & 0,32 & 0,27 & 0,32 & 0,24 & 0,32 & 0,32 & 0,29 & 0,29 \\
\hline 5 & O5 & 0,43 & 0,39 & 0,47 & 0,47 & 0,43 & 0,47 & 0,43 & 0,39 & 0,47 & 0,47 & 0,43 \\
\hline 6 & $\mathrm{O} 6$ & 0,35 & 0,39 & 0,35 & 0,39 & 0,43 & 0,47 & 0,43 & 0,47 & 0,43 & 0,47 & 0,43 \\
\hline \multicolumn{13}{|c|}{ Threats } \\
\hline 1 & $\mathrm{~T} 1$ & 0,22 & 0,28 & 0,28 & 0,38 & 0,35 & 0,38 & 0,28 & 0,38 & 0,31 & 0,38 & 0,31 \\
\hline 2 & $\mathrm{~T} 2$ & 0,33 & 0,36 & 0,40 & 0,40 & 0,30 & 0,40 & 0,36 & 0,40 & 0,33 & 0,40 & 0,36 \\
\hline 3 & $\mathrm{~T} 3$ & 0,30 & 0,26 & 0,26 & 0,40 & 0,36 & 0,33 & 0,30 & 0,40 & 0,40 & 0,33 & 0,30 \\
\hline 4 & $\mathrm{~T} 4$ & 0,22 & 0,28 & 0,25 & 0,38 & 0,35 & 0,38 & 0,31 & 0,38 & 0,38 & 0,38 & 0,35 \\
\hline \multicolumn{13}{|c|}{ Strengths } \\
\hline 1 & S1 & 0,32 & 0,35 & 0,32 & 0,35 & 0,29 & 0,35 & 0,32 & 0,35 & 0,35 & 0,32 & 0,32 \\
\hline 2 & $\mathrm{~S} 2$ & 0,32 & 0,35 & 0,29 & 0,32 & 0,32 & 0,32 & 0,26 & 0,29 & 0,35 & 0,29 & 0,32 \\
\hline 3 & S3 & 0,32 & 0,32 & 0,29 & 0,35 & 0,32 & 0,35 & 0,29 & 0,32 & 0,29 & 0,35 & 0,32 \\
\hline 4 & $\mathrm{~S} 4$ & 0,23 & 0,23 & 0,26 & 0,31 & 0,26 & 0,26 & 0,28 & 0,31 & 0,31 & 0,31 & 0,23 \\
\hline 5 & S5 & 0,17 & 0,21 & 0,17 & 0,25 & 0,23 & 0,25 & 0,19 & 0,25 & 0,23 & 0,25 & 0,23 \\
\hline 6 & S6 & 0,32 & 0,29 & 0,35 & 0,35 & 0,29 & 0,35 & 0,32 & 0,35 & 0,35 & 0,29 & 0,29 \\
\hline 7 & S7 & 0,25 & 0,27 & 0,27 & 0,30 & 0,27 & 0,25 & 0,22 & 0,30 & 0,27 & 0,30 & 0,27 \\
\hline 8 & S8 & 0,32 & 0,29 & 0,29 & 0,32 & 0,26 & 0,32 & 0,32 & 0,35 & 0,35 & 0,29 & 0,26 \\
\hline \multicolumn{13}{|c|}{ Weaknesses } \\
\hline 1 & W1 & 0,16 & 0,24 & 0,22 & 0,24 & 0,20 & 0,24 & 0,18 & 0,24 & 0,20 & 0,24 & 0,01 \\
\hline 2 & W2 & 0,23 & 0,23 & 0,28 & 0,28 & 0,21 & 0,28 & 0,26 & 0,28 & 0,28 & 0,28 & 0,02 \\
\hline 3 & W3 & 0,21 & 0,21 & 0,19 & 0,25 & 0,23 & 0,23 & 0,19 & 0,23 & 0,25 & 0,21 & 0,01 \\
\hline 4 & W4 & 0,17 & 0,19 & 0,19 & 0,25 & 0,23 & 0,25 & 0,23 & 0,25 & 0,25 & 0,25 & 0,02 \\
\hline 5 & W5 & 0,23 & 0,29 & 0,32 & 0,35 & 0,32 & 0,32 & 0,32 & 0,35 & 0,32 & 0,32 & 0,03 \\
\hline \multicolumn{2}{|c|}{ Total Score } & 6,27 & 6,70 & 6,76 & 7,84 & 6,99 & 7,68 & 6,82 & 7,81 & 7,57 & 7,63 & 5,88 \\
\hline \multicolumn{2}{|c|}{ Rank } & 10 & 9 & 8 & 1 & 6 & 3 & 7 & 2 & 5 & 4 & 11 \\
\hline
\end{tabular}

In determining the alternative strategies using the QSPM method, the attractiveness scores and total attractiveness scores were used. The QSPM analysis was based on the selection of strategies that are most preferred by respondents. The results show that the strategies that need to be implemented to develop religious tourism in Mount Haruman are follows:

1) TAS 4. Increasing the use of information and communication technology-based promotion to promote tourism potential that is not widely known by the public.

2) TAS 8. Increasing the sense of ownership of the community and visitors to preserve the nature so that the coolness of the air and its beautiful scenery are maintained; 
3) TAS 6. Improving the quality of human resources by fostering tourism to the community through counseling, training, and community empowerment;

4) TAS 10. Doing maintenance and repair of the infrastructure in order to improve visitor satisfaction;

5) TAS 9. Conducting tourism planning and development to optimize the utilization of the potential of Mount Haruman;

6) TAS 5. Providing and developing various tourism facilities that can generate comfort among visitors;

7) TAS 7. Improving the system of cooperation and coordination between the relevant agencies, private managers, and the community in utilizing and developing the tourism potential of Mount Haruman;

8) TAS 3. Providing the navigation that shows the direction and distance to the location of the religious tourism of Mount Haruman;

9) TAS 2. Holding special events in order to increase tourist visits. It can be done through a collaboration with Nahdlatul Ulama as the most dominant organization in making some changes in tourism areas or other religious institutions;

10) TAS 1. Developing the existing potential and improving its quality standards in order to add new tourist attractions and achieve visitor satisfaction;

11) TAS 11. Increasing visitor awareness of environmental cleanliness.

\section{Conclusion}

The present study investigated the development of religious tourism strategies on Mount Haruman. Based on the results and discussion presented in the previous sections, there were 23 SWOT components found which were then divided into two major factors namely internal and external. In regard to internal factors, there were 8 components of strengths and 5 components of weaknesses. Meanwhile, in terms of external factors, 6 opportunities and 4 threats emerged. Out of 23 SWOT components, 11 attractive strategies were proposed. Increasing the use of information and technology based promotion to promote tourism potential that is not widely known by the public, based on the accumulation of the total scores, is a superior strategy and become a main priority to be implemented by the stakeholders of Mount Haruman religious tourism management in the future. 


\section{Recommendation}

Based on the results of the study, there are some suggestions that can be offered to the management of Mount Haruman religious tourism. They are as follows:

1) Implementing the strategies generated from this present study in order to improve and develop tourism in Mount Haruman;

2) Establishing a good relationship between the local government and the surrounding community so that the same understanding and initiative related to development planning are achieved. It is also important to be done so that good communication and coordination can be carried out which may help avoiding the risk of tension between the local government and the local community;

3) Conducting effective and controlled cooperation among agencies, private parties, and business people. It is important to involve local communities and local governments that still lack a role in developing the potential of Mount Haruman. This cooperation should be done from the process of planning to the implementation of the program, so that all parties involved can carry out their respective roles properly, and the potential possessed by Mount Haruman can be utilized optimally. By involving the community in the process of planning, organizing, implementing, and monitoring, it is expected that the welfare of the surrounding community can be realized;

4) Developing while maintaining the authenticity of the site such as by avoiding the restoration of the tomb as mandated by Sheikh Jaffar Siddiq. Because he was a simple figure, he did not want his tomb to be made luxurious like those of other God's messagers;

5) Doing active promotion by utilizing information and communication-based technology that is currently used as a medium of tourism marketing. One of the forms of technology that can be used for promotion is social media, assisted or in collaboration with some influencers in the field of tourism, such as tourism ambassadors, and popular accounts;

6) Improving the ability and skills of the local community by providing tourism trainings or conducting community empowerment. The trainings can cover various aspects such as training for being a tour guide, and training to improve skill and creativity in making products or goods like souvenirs of Mount Haruman. Such a training is necessary so that people can trade with higher quality of goods and higher selling value. Training in 
providing services is also helpful and needed so that potential customers will feel interested and satisfied with the services provided.

\section{References}

Aini, H. (2015). Strategi Pengembangan Objek Wisata Unggulan Hapanasan Oleh Dinas Kebudayaan dan Pariwisata Rokan Hulu. Jurnal Online Mahasiswa Fakultas Ilmu Sosial $\begin{array}{clll}\text { dan } & \text { Ilmu } & \text { Politik, } & \text { Retrieved }\end{array}$ https://jom.unri.ac.id/index.php/JOMFSIP/article/view/5036.

Buhalis, D., \& Foerste, M. (2015). SoCoMo Marketing for Travel and Tourism: Empowering Co-Creation of Value. Journal of Destination Marketing $\mathcal{E}$ Management, 1-11. doi:https://doi.org/10.1016/j.jdmm.2015.04.001.

Butcher , J., \& Smith, P. (2017). Volunteer Tourism (Contemporary Geographies of Leisure, Tourism and Mobility). London: Routledge.

Coros, M. M., Gica, O. A., Yallop, A. C., \& Moisescu, O. I. (2017). Innovative and Sustainable Tourism Strategies: For Romania's Economic Development. Worldwide Hospitality and Tourism Themes, 1-13. doi:https://doi.org/10.1108/WHATT-07-2017-0033.

Cortez, S. L. (2010). Strategies For The Development of Sustainable Tourism In The Amazon Rainforest of Bolivia. Worldwide Hospitality and Tourism Themes, 136-143. doi:https://doi.org/10.1108/17554211011037822.

Cucculelli, M., \& Goffi, G. (2016). Does sustainability enhance tourism destination competitiveness? Evidence from Italian destinations of excellence. Journal of Cleaner Production, 111, 370-382.

Ene, S. G., \& Bărăitaru, M. (2010). Sustainable Development Strategies in Domestic and International Tourism. European Journal of Interdisciplinary Studies, 87-95. Retrieved from https://www.researchgate.net/publication/228243972_Sustainable_Development_Strate gies_in_Domestic_and_International_Tourism.

Grytsiuk, M., Grytsiuk, P., \& Gryciuk, Y. (2017). Building a Sustainable Tourism Development Strategy in The Carpathian Region of Ukraine. 35-50. doi:10.29119/1641-3466.2017.104.3.

Haq, F. M. (2014). The Significance of Partnership As A Marketing Strategic For Islamic $\begin{array}{lllll}\text { Spiritual Tourism. Journal of Islamic } & \text { Marketing, } 272 .\end{array}$ doi:https://doi.org/10.1108/JIMA-11-2013-0079. 
Imandaneifar, Azagh, E., Abangah, A., Sajadinasab, T., \& Ahmadi, M. (2014). Religious Tourism Development Strategies Using SWOT Strategic Models (Case Study: Emamzadehseyed Mahmoud (AS)). International Journal of Current Life Sciences, 69846988.

Retrieved

from

https://www.academia.edu/8741176/Religious_tourism_development_strategies_using _SWOT_strategic_models_Case_Study_Emamzadeh_Seyed_Mahmoud_AS_.

Indopos. (2018, Maret 12). Pariwisata Jadi Leading Sector, Garut Siapkan Banyak Destinasi. Retrieved from Indopos.co.id: https://indopos.co.id/read/2018/03/12/130657/pariwisatajadi-leading-sector-garut-siapkan-banyak-destinasi.

Jee, T.-W., Ting, H.-B., \& Alim, M. A. (2019). Community Based Tourism Re-Visit Intention: Tourists' Perspective. International Journal of Business and Society, 20(2), 585-604.

Kong, W. H., Cros, H. d., \& Ong, C.-E. (2015). Tourism Destination Image Development: A

Lesson from Macau. International Journal of Tourism Cities, 299-316. doi:https://doi.org/10.1108/IJTC-08-2014-0016.

Kotoua, S., \& Ilkan, M. (2017). Tourism Destination Marketing and Information Technology in Ghana. Journal of Destination Marketing $\mathcal{E}$ Management, 1-9. doi:https://doi.org/10.1016/j.jdmm.2017.04.007.

Luo, J., Ba, S., \& Zhang, H. (2012). The Effectiveness of Online Shopping Characteristics and Well-Designed Websites on Satisfaction. MIS Quarterly, 36(4), 1131-1144.

Pasya, G. K., \& Gitasiswhara, G. (2013). Integration of Religious Travel and Tourism in Java. Jurnal Pendidikan Ilmu Sosial, 22(1).

Ulumudin, A., Akbar, G. G., Kania, I., Pasciana, R., Pundenswari, P., \& Alamanda, D. T. (2019). In Search Of Divinity: Paving The Path For Spiritual Tourism In Garut Regency, Indonesia. The 2nd International Seminar Series on Regional Dynamics (ISSRD) (pp. 130139). Jember: UNEJ.

Wang, D., \& Xiang, Z. (2012). he new landscape of travel: A comprehensive analysis of smartphone apps. In M. Fuchs, F. Ricci, \& L. Cantoni, Information and Communication Technologies in Tourism (pp. 308-319). Wien: Springer. 